\title{
PERANCANGAN PROGRAM APLIKASI PERSEDIAAN SPAREPART MOTOR DENGAN MENGGUNAKAN BAHASA PEMROGRAMAN BORLAND DELPHI 7.0 PADA PD.KARTIKA MOTOR BANDAR LAMPUNG
}

\author{
Agus Sukoco \\ Program Studi Teknik Informatika \\ Fakultas Ilmu Komputer \\ Universitas Bandar Lampung \\ Jln. Z.A. Pagar Alam No.26 Labuhan Ratu Bandar Lampung 35142 \\ Telp. (0721) 701463, (0721) 701979 Fax. (0721) 701467 Web. www.ubl.ac.id
}

\begin{abstract}
Abstrak
Pada masa kini, perkembangan dan kemajuan teknologi informasi terus berjalan. Untuk dapat bersaing sesuai dengan perkembangan zaman, P.D Kartika meninggalkan cara manual dalam mencatat transaksi persediaan,penjualan dan pembelian sparepart. Karena akan mengurangi efektifitas kerja sehingga hasilnya kurang optimal.

PD.Kartika adalah sebuah perusahaan yang bergerak dibidang suku cadang motor, sebagai sebuah perusahaan yang sudah banyak dikenal kalangan masyarakat menengah, maka PD.Kartika berusaha untuk meningkatkan efektifitas kerja agar pelanggan dan kinerja didalam perusahaan tersebut lebih memuaskan.

Tujuan penyusunan laporan akhir studi ini adalah untuk menjabarkan, menggambarkan dan melaporkan hasil dari pelaksanaan penyusunan laporan akhir studi serta untuk memberikan pandangan dan pengalaman langsung didalam dunia kerja, sehingga mahasiswa dapat mengintegrasikan teori dan praktek yang diperoleh dibangku perkuliahan dengan kenyataan yang ada dilapangan

Kata Kunci : Perancangan, Program, Sistem, Data, Persediaan
\end{abstract}

\section{PENDAHULUAN}

Setiap organisasi atau perusahaan mempunyai suatu tujuan tertentu yang telah ditetapkan, tujuan tersebut akan tercapai jika terdapat faktor-faktor penunjang kelangsungan perusahaan antara lain : modal dan SDM. SDM dalam hal ini adalah tenaga kerja atau karyawan yang berperan langsung dalam proses penjualan barang.

PD. KARTIKA MOTOR adalah salah satu dari perusahaan dagang yang bergerak dibidang perdagangan yaitu sebagai pemasok spare spart yang bertujuan untuk memenuhi kebutuhan masyarakat yang membutuhkan. Sehingga untuk lebih meningkatkan pelayanan yang lebih memuaskan harus ditunjang oleh sumber daya manusia dan peralatan yang sesuai sehingga hasil yang diharapkan oleh konsumen sebagai pengguna merasa puas dengan pelayanan yang cepat dan merasa lebih dekat dengan mereka. 1.2 Identifikasi Masalah.

Pada saat ini PD KARTIKA MOTOR Bandar Lampung administrasi penjualan,pada bagian ini semua aktifitas penjualan mulai dari pengecekan
Tetapi ada hal yang masih dilakukan secara sederhana,hal ini terdapat pada bagian administrasi yang merupakan kunci dari semua aktivitas penjualan yang dilakukan pada perusahaan dagang.

Untuk dapat melakukan pengecekan kegiatan permintaan, pembelian sampai pengadaan suku cadang membutuhkan proses yang sedikit lama, karena bagian administrasi harus mengecek serta melakukan pelayanan dengan cara manual tanpa menggunakan komputer dan sistem yang lebih mudah dalam hal ini adalah sistem komputerisasi. Untuk mengetahui persediaan barang yang masih tersedia pada akhir periode masih dilakukan secara manual, dan sama sekali belum menggunakan sistem computer.

barang yang masih tersedia(persediaan barang) sampai dengan pembuatan laporan yang diambil dari data permintaan dan pembelian masih dilakukan secara manual. Dalam proses penjualan 
dimana data-data masih dilakukan secara manual dengan menggunakan sistem pembukuan. Laporan penjualan dibuat secara terpisah antara data pembelian, penjualan maupun persediaan barang, hal itu menyebabkan proses pengecekan data persediaan barang pada akhir periode membutuhkan waktu yang cukup lama karena harus mencari berkasnya dan melihat catatan pembukuan terlebih dahulu. Penyebab belum optimalnya aktifitas kerja pada bagian administrasi penjualan termasuk persediaannya pada PD. Kartika Motor dikarenakan kurang efektifnya sistem informasi manajemen yang digunakan..

\subsection{Perumusan Masalah.}

Berdasarkan identifikasi masalah maka peneliti ingin membantu merancang sebuah program aplikasi tentang informasi persediaan untuk PD.KARTIKA MOTOR dengan menggunakan Bahasa Pemrograman Borland Delphi 7.0

\subsection{Batasan Masalah}

Untuk mempermudah proses pembuatan penelitian Tugas Akhir dan proses pembuatan aplikasi program persediaan spare part pada PD. Kartika Motor maka peneliti membatasi masalah penelitian Tugas Akhir ini meliputi perancangan aplikasi yang terdiri dari :

1. Rancangan Input :

- Menginput, mencari, melihat, mengedit data penjualan, pembeliaan \& persediaan barang

- Menginput, mencari, melihat, mengedit dan menyimpan data barang dan suplier

2. Rancangan Output :

- berupa pembuatan faktur penjualan, faktur retur pembelian dan pembelian serta laporan penjualan ,pembelian dan persediaan barang pada PD. Kartika Motor.

- Aplikasi perancangan Data Base pada sistem Informasi persediaan pada PD. Kartika Motor menggunakan paradox.

- Bahasa pemrograman yang digunakan untuk membuat sistem Informasi Persediaan pada PD. Kartika Motor adalah Borland Delphi 7.0.

\subsection{TUJUAN DAN MANFAAT PENELITIAN}

\subsubsection{Tujuan Penelitian \\ Tujuan Peneliti}

membuat aplikasi program ini adalah :

1. Peneliti ingin membantu PD. Kartika motor dalam melakukan aktifitas agar kerjanya lebih efektif dan efesien.

2. Peneliti ingin memperkenalkan bahasa pemrograman Borland Delphi 7.0 sebagai salah satu dari banyak bahasa pemrograman lain yang dapat memberikan kemudahan dan kelancaran dalam menyelesaikan pekerjaan sehari-hari untuk PD.Kartika.

3. Peneliti ingin mengetahui bagaimana perbandingan waktu hasil yang dicapai sebelum dan sesudah program aplikasi ini dibuat untuk kelancaran aktifitas kerja PD.Kartika.

\subsubsection{Manfaat Penelitian}

Program aplikasi yang dibuat dengan menggunakan bahasa pemrograman Borland Delphi 7.0 diharapkan dapat memberikan manfaat, diantaranya :

1. Mempermudah dalam melakukan pengecekan pengambilan barang dan persediaan barang yang masih ada/tersedia.

2. Mempermudah dan mempercepat proses pembuatan laporan penjualan, pembelian dan persediaan barang dalam satu periode/satu tahun berjalan.

3. Dapat mempraktekkan ilmu yang selama ini diperoleh guna meningkatkan kemampuan dalam membuat program aplikasi.

\section{LANDASAN TEORI}

\subsection{PERANCANGAN PROGRAM APLIKASI} 2.1.1 Definisi Perancangan

Perancangan adalah proses, cara, perbuatan merancang. ( Tim Penyusun Kamus Besar Bahasa Indonesia Depdikbud, $1990 ; 725$ )

\subsubsection{Definisi Aplikasi}

Definisi aplikasi menurut kamus komputer adalah program software atau paket program yang dibuat untuk melaksanakan suatu fungsi bagi pengguna (program siap pakai). Aplikasi akan menggunakan sistem operasi (OS) komputer yang mendukung. Biasanya istilah aplikasi dipakai dengan nama program, misalnya aplikasi $M S$ Word.

\subsection{KONSEP DASAR SISTEM}

\subsubsection{Definisi Sistem}

Sistem adalah sekumpulan hal atau kegiatan atau elemen atau subsistem yang saling bekerjasama atau yang dihubungkan dengan cara-cara tertentu sehingga membentuk satu kesatuan untuk melaksanakan suatu fungsi guna mencapai suatu tujuan. ( Edhy Sutanta, 2003 : 4)Sistem adalah sekelompok unsur yang erat hubungannya satu dengan yang lain, yang berfungsi bersama- sama untuk mencapai tujuan tertentu.(Tata Sutabri,2004 :9).

Sebuah sistem juga dapat didefinisikan sebagai suatu kesatuan yang terdiri dari dua atau lebih 
komponen atau subsistem yang berinteraksi untuk mencapai suatu tujuan. (Jogianto, 1999 : 683)

\subsection{Tahap-tahapPerancangan Program}

Untuk membuat / menyusun suatu program yang besar dan komplek, pemrograman membutuhkan beberapa tahapan-tahapan yang sistematis dan terpadu, yaitu :

\section{Definisi Masalah}

Pendefinisian masalah untuk mendapatkan pemahaman tentang permasalahan yang ada, sehingga akan diperoleh asumsi-asumsi yang benar untuk dapat memecahkan permasalahan. Langkah-langkah pendefinisian masalah adalah sebagai berikut :

a. Pemahaman permasalahan.

Pemahaman permasalahan sangat penting, karena sering sekali terjadi persepsi yang berbeda didalam pemahaman permasalahan, sehingga akhirnya tidak mendapatkan pemecahan masalah yang tepat.

b. Identifikasi masalah

Disini pemrogram dapat mengungkapkan kemungkinan permasalahan yang muncul pada saat pembuatan program dilaksanakan.( Indra Yatini B : $2001: 6$ )

\section{Analisis Kebutuhan}

Analisis kebutuhan merupakan aktifitas komunikasi yang paling intensif dan merupakan tugas utama yaitu, pengenalan masalah eveluasi masalah serta sistesis yang merupakan 2 tugas yang harus dikuasai dengan mahir untuk mendapatkan informasi yang dibutuhkan. Ada beberapa hal yang mendasari timbulnya permasalahan pada tahap analisis kebutuhan, antara lain :

a. Komunikasi yang jelek antara pemakai dan analisis.

b. Teknik yang digunakan kurang baik dan alat bantu yang digunakan juga kurang baik sehingga spesifikasi kurang baik dan kurang akurat.

c. Kecendrungan kurang memperpendek waktu analisis. Gagal dalam mempertimbangkan alternatif pemecahan masalah.

( Indra Yatini B : $2001: 2$ )

\section{Desain Algoritma}

Desain algoritma dibuat sama dengan menuliskan langkah-langkah dalam pemecahan masalah yang ada, karena algoritma dibuat dengan tujuan untuk menyelesikan sutu permasalahan. Algoritma yang dibuat tidak langsung jadi dan harus dikaji terusmenerus, sehingga akan diperoleh algoritma yang paling relevan, karena harus memiliki kebenaran secara logika sebelum siap untuk diimplementasikan dalam bentuk program.Fase dari desain algoritma terlengkap bila telah mempumyai suatu deskripsi penuh, dan bila kajian yang telah dilakukan tidak lagi menyingkap permasalahan, berat telah siap untuk melngkah dengan pengkodean. ( Indra Yatini B : $2001: 7,8$ )

\section{Pengkodean}

Pengkodean adalah kemudahan yang didapat pemeliharaan maupun dalam mengerti kode sumber yang telah dibuat. Pengkodean menekankan kepada kesederhanaan dan kejelasan pengkodean meliputi . ( Indra Yatini B : $2001: 8$ )

\section{a. Dokumentasi kode}

Dokumentasi kode atau dokumentasi program sumber dimulai dengan pemilihan identifier ( variable dan label ), kemudian dilanjutkan dengan penyusunan komentar serta penggambaran dari organisasi program yang telah dibuat. Pemilihan nama pada identifier yang mudah dimengerti merupakan bagian yang paling kritis, karena banyak bahasa pemrograman yang mempunyai keterbatasan pada saat pemberian nama untuk variable.

\section{b. Deklarasi data}

Deklarasi data ditentukan apabila kode telah dibuat dan terdapat sejumlah petunjuk yang dapat digunakan untuk membuat data mudah dimengerti dan mudah pemeliharaannya.

\section{c. Penyusunan perintah}

Penyususnan perintah merupakan bagian dari langkah pengkodean, karena banyak dari bahasa pemrograman yang mengijinkan lebih dari satu perintah dalam satu baris. Pentusunan perintah dapat dipermudah dengan megikuti petunjuk sebagai berikut :

- menghindari pemakaian tes kondisi yang berbelit-belit

- menjabarkan tes pada kondisi yang salah

- menghindari pemakaian perulangan yang berbelit-belit

- menggunakan tanda kurung untuk pembuatan ekspresi logika atau aritmatika

- menggunakan spasi atau simbol yang dapat dibaca untuk menjelaskan isi dari perintah

\section{d. Input / Output}


Petunujuk yang dapat digunakan dalam perncangan dan pengkodean input / output adalah

- validasi seluruh data input

- cek keusangan terhadap seluruh kombinasi dari item input

- membuat format input dan output yang mudah

\section{e. Efisiensi}

Efisiensi merupakan tujuan yang harus dicapai dalam pengkodean, efisiesi yang harus dicapai meliputi :

- efisiensi kode yang merupakan satu kesatuan dengan efisiensi algoritma yang telah didefinisikan pada tahap perancangan.efisiensi memori adalah keefisienan perintah dalam program dan dalam menggunakan memori baik untuk pelaksanaaan ataupun pada penyimpanan data.

\section{Bahasa Pemrograman}

Di dalam pengkodean adalah menterjemahkan desain ke dalam bahasa pemrograman aktual, sebagian besar kesulitan telah harus terpecahkan pada tahap sebelumnya, sehingga pemrogram bebas untuk mencurahkan perhatian penuh untuk pembuatan program.

Bahasa pemrograman merupakan kendaraan yang digunakan untuk berkomunikasi antara manusia dengan mesin komputer. Karakteristik dari bahasa pemrograman mempunyai pengaruh yang penting dari kualitas komunikasi, begitu juga kerekayasaan bahasa pemrograman mempunyai pengaruh yang penting terhadap berhasil tidaknya suatu program yang akan di buat. Pemilihan bahasa pemrograman, yang merupakan hal yang sangat penting bagi pemrogram untuk mulai membuat program. Fungsi dari bahasa pemrograman adalah sebagai media untuk membuat program dan memahami serta sebagai alat komunikasi antara pemrogram dan komputer. Pemilihan bahasa pemrograman harus tepat dan sesuai dengan permasalahan yang ada.

Beberapa kriteria yang digunakan untuk mengevaluasi pemilihan bahasa pemrograman yaitu :

1. Bidang aplikasi yang sedang dikerjakan

2. Kekomplekskan algoritma dan perhitungan

3. Lingkungan dimana perangkat lunak akan diterapkan

4. Pengetahuan staf akan bahasa pemrograman

5. Ketersediaan kompiler yang baik ( Indra Yatini B : $2001: 9$ )

\section{Testing dan Debugging}

Testing merupakan elemen yang paling kristis dari perangkat lunak ( program) yang telah selesai dikerjakan. Setelah selesai tahap pengkodean diharapkan program harus tidak mengandung error untuk mendeteksi dan mengoreksi error dapat menjadi usaha yang besar.

Testing adalah menguji program sampai dipenuhi bebas error lewat bermacam-macam kondisi atau dengan input yang hasilnya dapat diprediksi. Testing tidak dapat secara absolut bisa yakin bahwa program adalah benar. Untuk program besar bisa jadi setelah dipakai sekian lama kemudian diketemukan error.

Debugging adalah mengoreksi error yang terdeteksi meliputi menetapkan lokasi kode yang error dan mengoreksinya. Debugging adalah penghilangan semua kesalahan yang ditemukan oleh pengujian dan bisa sangat memakan waktu, terutama pada saat pembuatan program melakukan kecerobohan desain dan pengkodean. Banyak dari debugging melibatkan koreksi kesalahan sehubungan dengan implementasi yang tidak benar dari algoritma dari yang dimaksudkan, tidak ada batasan dari jenis implementasi error yang dibuat, berikut ini beberapa yang paling umum :

\section{Error Spesifikasi}

Program yang ditulis dengan spesifikasi yang tidak benar, misalnya error dalam algoritma.

\section{Error Sintax}

Muncul dari pengetikan statement yang tidak dimengerti oleh bahasa yang dipakai. Error ini paling mudah dikoreksi karena kompiler dapat memberitahu dibaris keberapa error dapat diketemukan.

\section{Error Eksekusi}

Dapat muncul pada saat program dijalankan, misalnya division by zero atau kondisi index yang tidak benar atau data yang tidak tepat yaitu data yang tidak sesuai dengan yang diminta program dan validasi input tidak mendeteksi error ini.

\section{Error Implementasi}

Implementasi yang salah dari algoritma yangdikembangkan,

Misalnya :

- penamaan variabel yang salah

- inisialisasi variable yang tidak benar

- kontrol loop yang tidak benar

- kontruksi bahasa yang tidak dimengerti 
Kesulitan utama pada debugging adalah untuk melacak kesalahan, yaitu mencari pernyataan atau bagoan dari suatu program dimana kesalahan terjadi. Begitu letak kesalahan diketahui, sebuah pembacaan mengenai bagian yang salah tersebut biasanya akan mengungkap sumber dari kesalahan yang ada. ( Indra Yatini B : 2001 : 7,130,133 )

\section{Dokumentasi}

Dokumentasi merupakan informasi dan gambaran tambahan yang sangat membantu untuk memahami sebuah kode yang diberikan. Tujuannya adalah untuk menjadi pedoman dan penjelasan bagi para pemakai. Dokumentasi dapat dibedakan, yaitu dokumentasi internal dan dokumentasi eksternal. Dokumentasi internal sebenarnya merupakan bagian kode hanya sebuah eksplansi dari berbagai aspek lewat komentar. Dokumentasi eksternal adalah dalam bentuk manual dan catatan-catatan penting tentang program. Dokumentasi internal dan eksternal harus konsisten satu sama lain dengan kode. ( Indra Yatini B : 2001 : 10 ) ( Indra Yatini B : $2001: 11,12$ )

\subsubsection{Definisi Inventory Stock Control}

Setiap perusahaan memerlukan perencanaan dalam hal pengendalian persediaan barang, karena tanpa adanya persediaan maka perusahaan tersebut akan menghadapi resiko ketidakmampuan dalam memenuhi keinginan para client, oleh sebab itu perlu adanya pengendalian persediaan, sedangkan pengendalian persediaan meliputi keputusan mengenai kapan harus melakukan pemesanan terhadap suatu item, dan berapa jumlah item yang harus dipesan.

Adapun Penyebab timbulnya persediaan dalam suatu perusahaan adalah karena adanya mekanisme pemenuhan permintaan. Permintaan terhadap suatu barang sering kali tidak serta merta dapat terpenuhi, karena pengadaan barang memerlukan tenggang waktu ( lead-time), dan selama tenggang waktu itulah perlu adanya pengendalian persediaan barang, sehingga keberlangsungan aktivitas dalam pelayanan kepada client dapat terjaga dengan baik.

Sehingga dari uraian diatas dapat didefinisikan bahwa Inventory Stock Control adalah serangkain kebijakan dan pengendalian yang menentukan ukuran dan mengawasi tingkat persediaan, kapan persediaan harus disediakan, dan berapa jumlah yang harus disiapkan. ( Smith )

\subsubsection{Fungsi Inventory Stock Control}

Persediaan timbul disebabkan oleh tidak sinkronnya permintaan dengan penyediaan dan waktu proses, maka diperlukan persediaan.

Oleh karena itu maka Inventory Stock Control ini memiliki fungsi, yaitu :

a. menetapkan dan menjamin tersedianya barang secara tepat jumlah dan tepat waktu

b. menghilangkan resiko keterlambatan datangnya barang yang dibutuhkan

c. menghilangkan resiko pengembalian mutu barang yang tidak baik sehingga harus dikembalikan

d. memberikan pelayanan dengan sebaikbaiknya dimana keinginan client pada suatu waktu dapat dipenuhi dengan memberikan jaminan tetap tersedianya barang yang dibutuhkan

\section{PERANCANGAN SISTEM}

\subsection{SISTEM YANG AKAN DIUSULKAN}

Dengan menggunakan Borland Delphi 7.0, maka dalam merancang program penjualan dan persediaan spart part memiliki kelebihan dibandingkan dengan sistem manual yang sekarang sedang digunakan sebelumnya, yaitu :

1. Mudah dalam melakukan pengecekan persediaan barang yang masih tersisa

2. Membuat laporan penjualan,pembelian, persediaan lebih baik dan akurat.

3. Mempercepat proses pembuatan laporan.

Berdasarkan permasalahan tersebut diatas maka,spesifikasi minimal terminal komputer dan perangkat lunak yang diusulkan atau konfigurasi sistem single user dam Multi user, adalah sebagai berikut :

\section{Single User}

\section{Hardware :}

a) Processor Intel pentium 4 berkecepatan Min 2,2 GHz

b) Hard Disk Min. 40 GB.

c) RAM Min $256 \mathrm{MB}$.

d) 1 buah monitor SVGA

e) Keyboard + Mouse

f) Printer Dot matrik

\section{Software :}

a) Menggunakan basis Windows ME keatas

b) Borland Delphi 7.0

c) Database menggunakan Paradox 7.0

Kelebihan :

1. Biaya keseluruhan lebih murah. 
2. Pemakaian waktu lebih efisien, waktu pengecekan lebih cepat.

3. Perawatan ( maintenance) lebih murah.

Kekurangan :

1. Masih ada yang menggunakan sistem manual sehingga kurang efektif dan efisien.

2. Waktu yang dibutuhkan dalam pengecekan lebih lama.

\section{Multi User}

\section{A. Server :}

\section{Hardware :}

a. Processor Intel pentium 4 berkecepatan $\min 2,4 \mathrm{GHz}$.

b. RAM $512 \mathrm{MB}$

c. Hard Disk $40 \mathrm{~GB}$

d. Mouse + Keyboard

e. LAN Card

f. Printer dot matrik.

g. 1 buah monitor SVGA

\section{Software :}

a. Operating System Basis Windows 2000 Server

b. Borland Delphi 7.0

c. Microsoft SQL server 2000

d. Database Paradox 7.0

Jaringan LAN (Local Area Network):

a. Menggunakan Switch.

b. Menggunakan UTP Cable

c. Mengguunakan Topologi STAR

B. Client ( 2 unit ) :

Hardware :

a. Processor Intel pentium 4 berkecepatan Min 1,6 GHz.

b. Hard Disk Min. 10 GB.

c. RAM Min $128 \mathrm{MB}$.

d. 2 buah Monitor SVGA

e. Keyboard + Mouse
f. Printer Dot matrik
g. LAN Card

\section{Software :}

a. Operating System Basis Windows 2000 Server keatas

b. Database Paradox 7.0

c. Borland Delphi 7.0

\section{Kelebihan :}

1. Lebih familier dan sudah user friendly ( lebih mudah ).

2. Waktu pengecekan lebih cepat.

\section{Kekurangan :}

1. Perawatan (maintenance) lebih sulit dan mahal.

2. Biaya keseluruhan cenderung lebih mahal.

\subsection{Flow of Document}

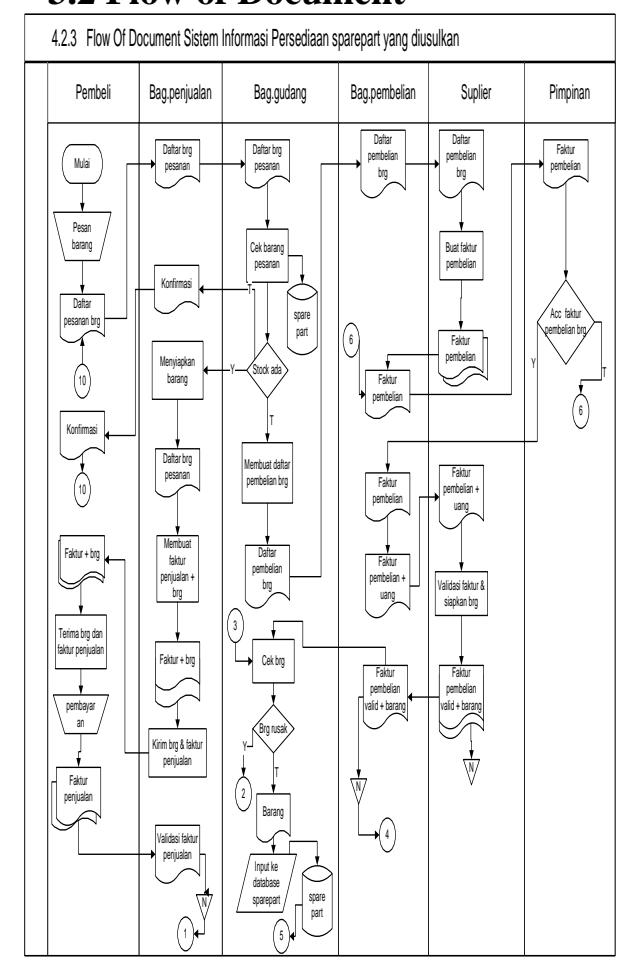




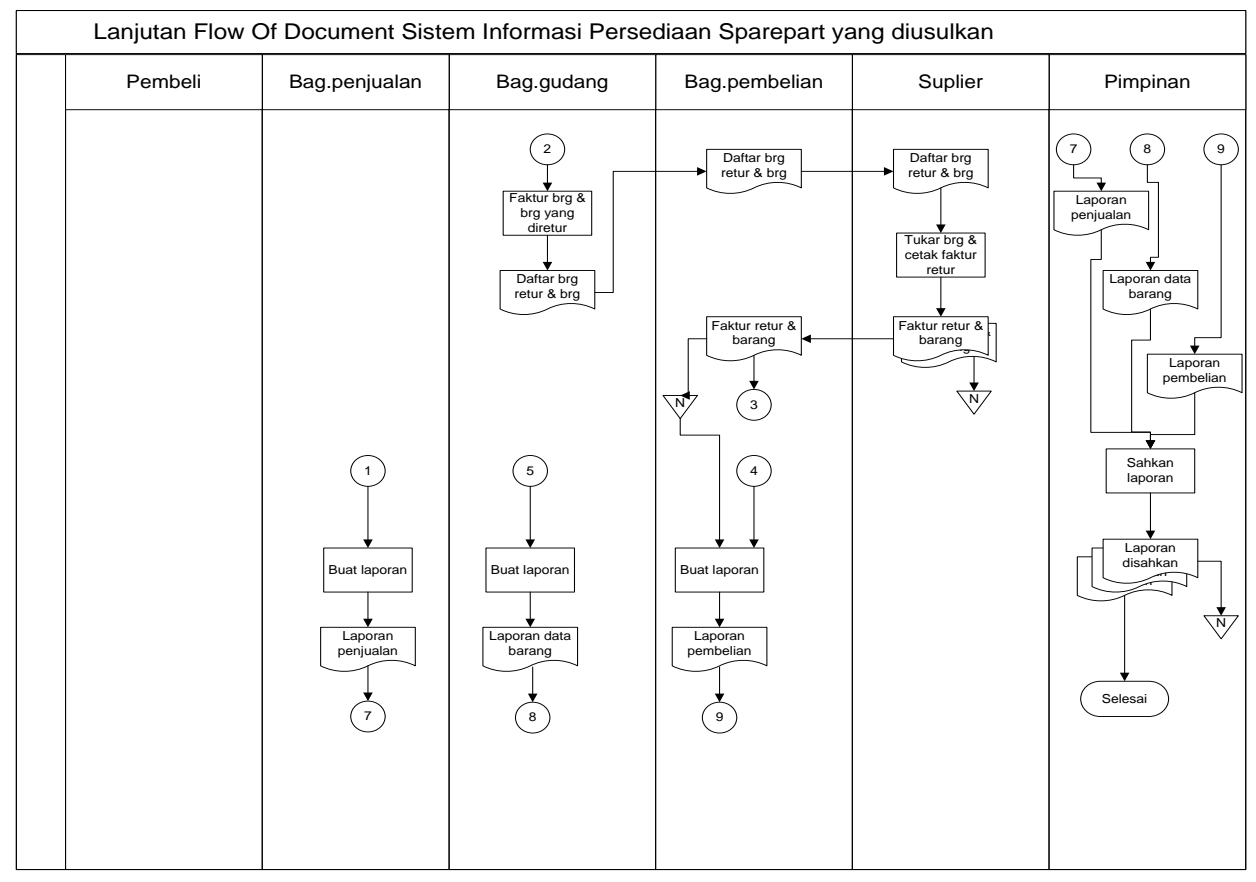

\subsection{Perancangan Database dan ERD}

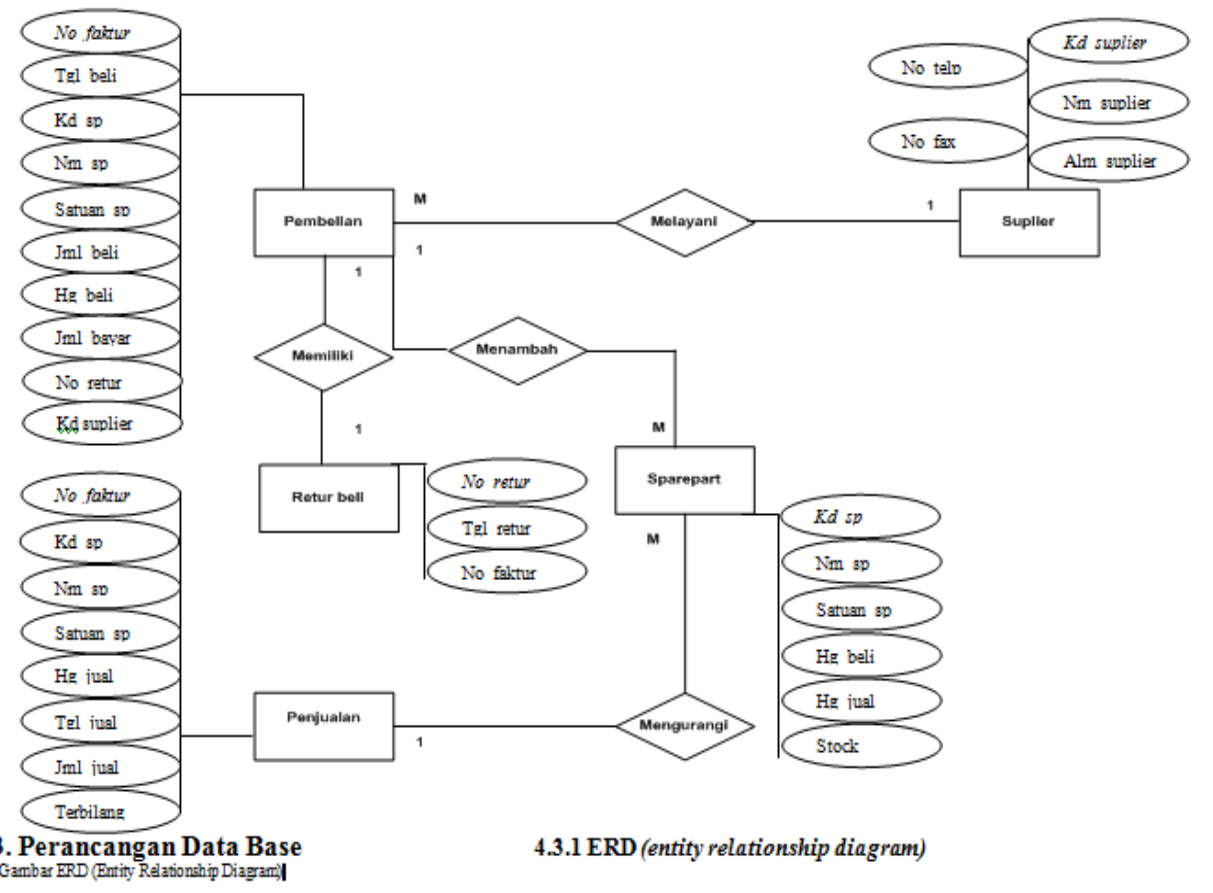

\subsection{PEMBAHASAN \\ 4.1.1 Perancangan Input}




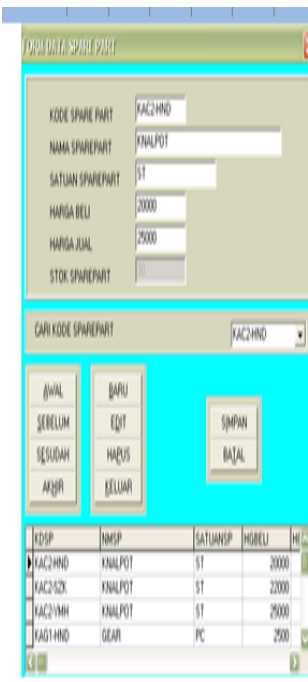

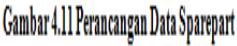

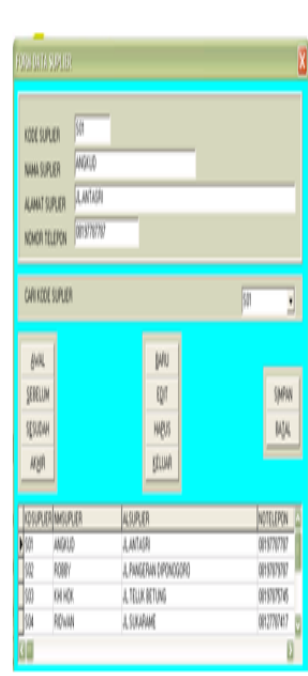

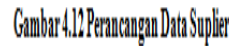

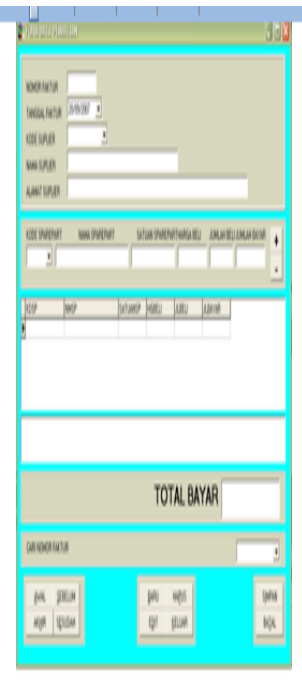

Gambrathlis

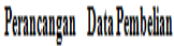

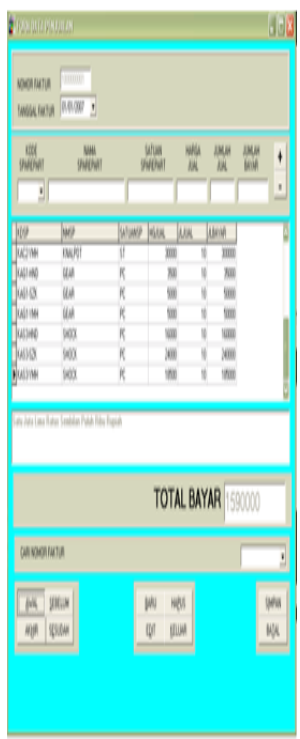

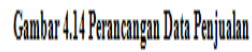
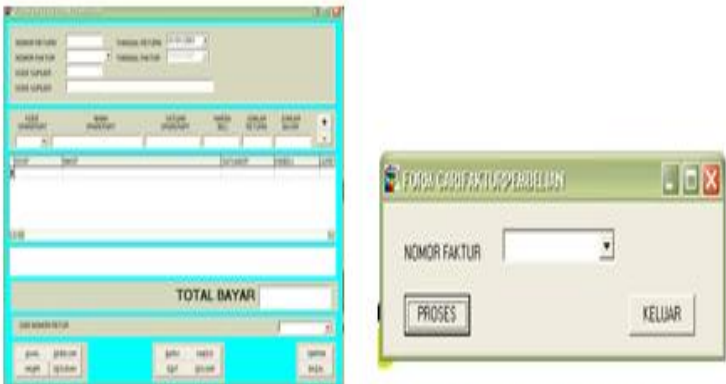

Gambar 4.15 Perancaugau Data Retur Pembelian

Gambar 4.19 Perancangan Data Pembelian

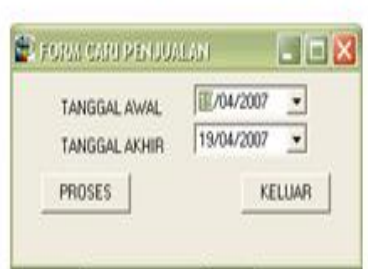

Berdasarkan No Faktur

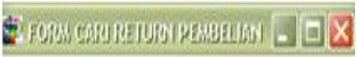

TANGGALAWAL TI/04/2007

TANGGALAKHIR 19/04/2007

PROSES

KEWAR

Gambar 4.16 Peraucaugan Data Peujualan Berdasarkau Tanggal -Retur Penbelian Berdasarkan Tanggal

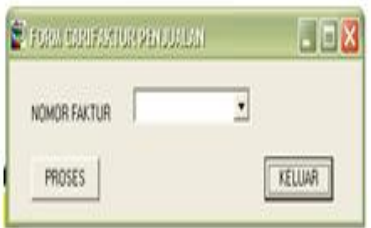

Gambar 4.17 Peraucaugan Data Peujualau Berdasarlian No Faltur

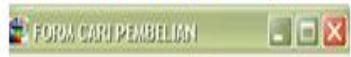

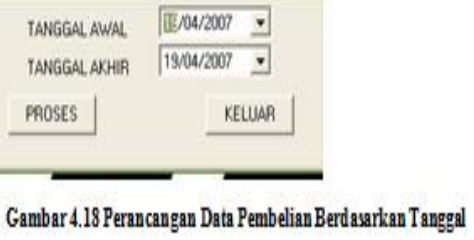

\subsubsection{Output}




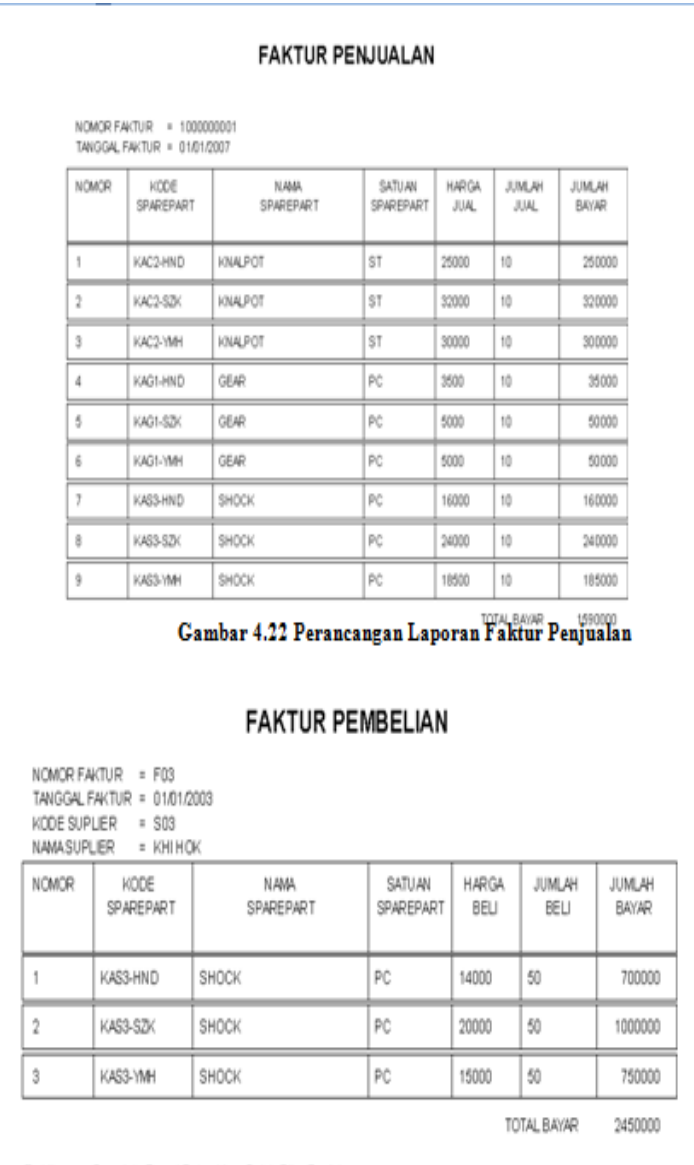

Tetoliang: Dua Jua EmpatRates Lima Putur Ribu Rupian

Gambar 4.23 Perancangan Laporan Faktur Pembelian

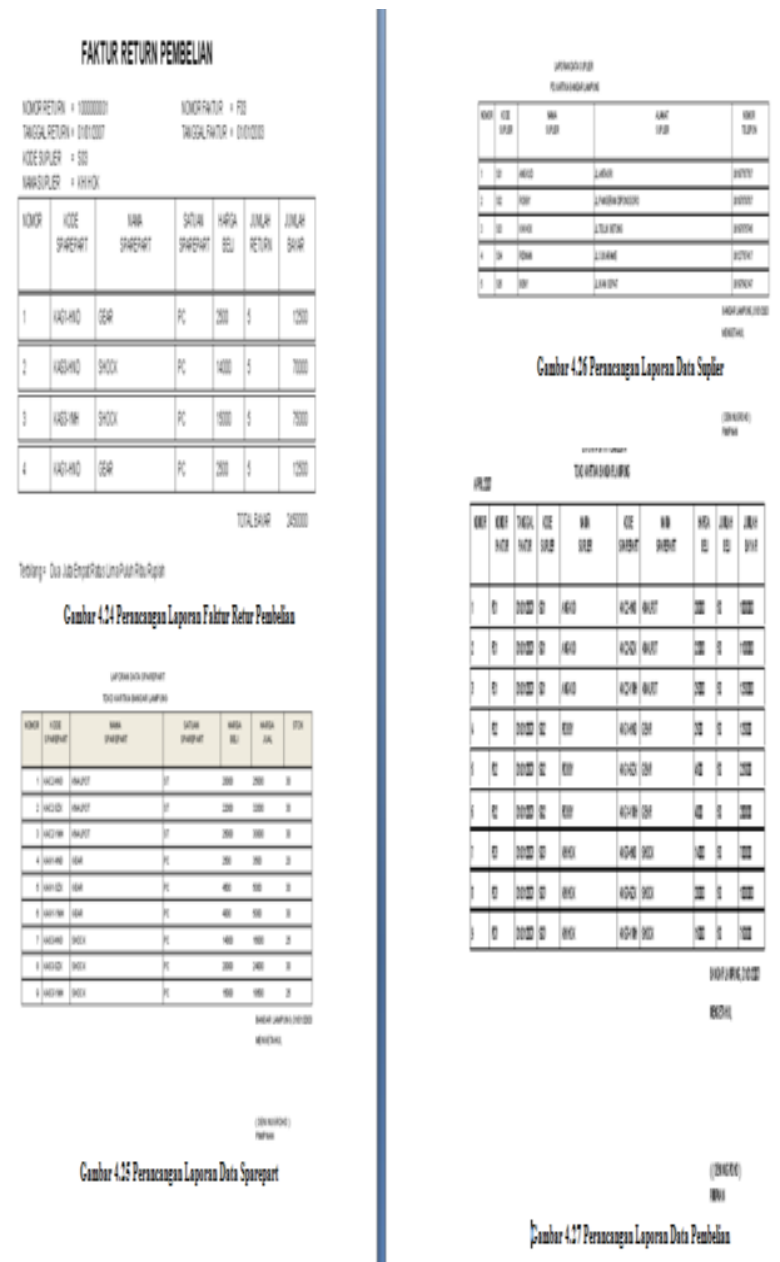

5. KESIMPULAN DAN SARAN

\subsection{SIMPULAN}

Berdasarkan dari analisis sistem yang telah dilakukan terhadap sistem yang berjalan sekarang pada PD.Kartika Motor, maka peneliti menarik simpulan sebagai berikut :

1. Proses pencatatan transaksi penjualan, pembelian dan persediaan sparepart pada PD.Kartika telah menggunakan komputerisasi. Kesalahan akibat human error dalam memasukkan data transaksi masih dapat terjadi.

2. Proses transaksi penyediaan sparepart pada PD.Kartika hanya dikhususkan pada supliersuplier yang telah tercatat di perusahaan tersebut saja.

3. Dengan menggunakan Ms. Borland Delphi 7.0, diharapkan dapat membantu penyimpanan data transaksi penjualan,persediaan dan pembelian sparepart serta interface program yang lebih userfrendly pada PD.Kartika.

\subsection{SARAN}


Dari kesimpulan-kesimpulan diatas, peneliti memberikan saran-saran kepada PD.Kartika Motor yaitu :

1. Seiring dengan perkembangan zaman yang terus maju, dan persaingan yang semakin ketat, maka disarankan kepada PD.Kartika Motor untuk meningkatkan lagi kinerja nya, khususnya yang menangani persediaan sparepart, yaitu dengan mengajarkan sistem komputerisasi kepada seluruh anggota karyawan.

2. Dalam memasukan transaksi pembelian dan penjualan serta persediaan sparepart diharapkan ketelitian staff dalam pemasukan data laporan untuk menghindari terjadinya human error.

3. Pada program aplikasi persediaan sparepart pada PD.Kartika diharapkan dapat memakai Ms. Borland Delphi 7.0, yang dapat membantu penginputan transaksi persediaan sparepart dan dengan interface yang lebih user frendly.

\section{DAFTAR PUSTAKA}

[1]Fathansyah,1999, Basis Data, Informatika Bandung

[2]Husni, 2004 ,Pemrograman Database dengan Delphi, Graha Ilmu

[3]Indra Yatini. B, Pemrograman Terstruktur, Penerbit J \& J Learning, Yogyakarta

[4]Inge Martina, Ir, 2000 Delphi 7.0, PT. Elex Media Komputindo

[5]Jogiyanto HM, 1999, Analisis dan Desain Sistem Informasi, Penerbit Andi Yogyakarta

[6]Jogiyanto HM, 1989, Analisis dan Desain Sistem Informasi, Penerbit Andi Yogyakarta

[7]Moh Nasir. Ph.D, 1988,Metodologi Penelitian, Penerbit Graha Indonesia

[8]Tata Sutabri, S.Kom MM, 2004,Analisis Sistem Informasi, Penerbit AndiYogyakarta

[9]Philip Kottler, 2002, Manajemen Pemasaran 